\title{
The Influence of Controlling System and Organizational Structuring Towards Employee Performance
}

\author{
Sahudi ${ }^{1}$, Benyamin Harits ${ }^{2}$, Iwan Satibi ${ }^{3}$ \\ ${ }^{1}$ Doctoral Program in Postgraduate Social Sciences, Pasundan University, Bandung, Indonesia \\ ${ }^{2,3}$ Pasundan University, Bandung, Indonesia \\ Email: sahudibanjar@gmail.com
}

\begin{abstract}
This research starts from the fundamental problems of low performance of employees at the Agency of Empowerment of Community and Village, Nation Unity and Politics at City of Banjar. Its thought to have been came by Controling System and Organizational Structuring towards Employee Performance at the Agency of Empowerment of Community and Village, Nation Unity and Politics at City of Banjar, not yet implemented. The approach in this study refers to the context of the theory of Controling System and Organizational Structuring also Employee Performance as part of the scope of Public Administration. The method of research used explanatory survey with technical analysis Structural Equation Modeling (SEM), while the population is Agency of Empowerment of Community and Village, Nation Unity and Politics at City of Banjar. The results of the study showed the need for further research on the optimization of the increasing influence of Controling System and Organizational Structuring on Employee Performance at the Agency of Empowerment of Community and Village, Nation Unity and Politics at City of Banjar, viewed from the perspective of Public Administration. This is indicated by the existence of other variables that influence the Employee Performance at the Agency of Empowerment of Community and Village, Nation Unity and Politics at City of Banjar.
\end{abstract}

Keywords: Controlling System, Organizational Structuring, Employee Performance.

\section{A. InTRODUCTION}

At present the world is entering the era of globalization. The era which is the process of globalizing the world, when the world order is global and knows no boundaries (Salim \& Sari, 2014). The era of globalization is often also called the era of initialization, which is an era in which global processes occur. This global process has taken place since the 1980s, precisely in various fields or aspects of human life, both in the political, social, economic, religious and especially globalization fields in technology.

The era of globalization is described as a period of time in which real global processes occur, everything that happens in one part of the world, also occurs in other parts, because of the acceleration of information through digital transportation and communication technology. The phenomenon that shows the sophistication and ability of transportation technology and communication technology to connect humanity in all parts of the world, so as to create a community life that includes all of humanity with a history of shared life in human history (Thereana, 2018). 
The influence of the globalization era can bring positive or negative impacts. The positive impact allows a major change in the pattern of human life, among others: the workings of people who are faster, more active to utilize and deepen their life capacity and increasingly want to display their human values and cultural identity. While the negative impact of the globalization era, among others: the occurrence of cultural imperialism from developed countries over developing countries and led to the emergence of individualistic societies that are not religious.

This negative impact will provide poor access to various segments of the organization including government organizations and their human resources that require a more humane approach in the form of a more specific approach to care, mentoring and coaching. In organizational activities, a holistic approach needs to be taken so that each component of the organization, especially employees, can work responsibly and be aware of the task demands that require the skills, caution and care that all organizational instruments must carry.

One of many ways to show the attitude of being aware of the duties and responsibilities at work requires the expertise of the manager of the organization is to create a model of a control system, so all the components of the organization from top to bottom can work with full diligence and control and do not take actions that can be detrimental overall organization. As revealed by Anthony \& Govindarajan (1995), an organizational control system, also commonly referred to as an administrative or bureaucratic control system, is designed to direct or regulate the activities of organizational members to match what is desired by the leadership of the organization.

The control system referred to is a means of gathering and using information to assist and coordinate the planning process. According to Mulyadi \& Setiawan (2001), which states that: "The management control system is a system used to plan various activities for the realization of the organization's vision through the chosen mission and to implement and monitor the implementation of the planned activity".

The nature of the control system is basically a system used by management to build the future of the organization in a better way. In building a better organization, it is necessary to determine in advance the mission of the organization as 'the chosen track' or in other words choose the path to bring the organization to realize its future.

After the organization's mission is determined, the next step that need to be taken by the organization is to describe the condition of the organization in the future by describing the future condition of the organization as the organization's vision. To realize the vision of the organization, through the chosen mission it is also necessary to organize the organization effectively and fundamentally so that a breakthrough occurs for the demands of organizational change in accordance with current needs.

Organizational structuring can be done in various forms, including through reorganization, both large and small scale. Large-scale changes in organizational structuring can take the form of an organizational structure overhaul, development of work 
units or even reduction of positions as a form of rationalization of needs in various sectors of existing work units. While on a small scale, internal arrangements in the form of promotions and job transfers within the organization's work unit environment.

Organizational structuring is one form of organizational change by restructuring the organization, both in structuring the structure and structuring of its human resources, even the addition or reduction of positions or work units. The purpose of organizational structuring, among others, to streamline work patterns and increase the efficiency of excessive use of material. French \& Bell (1981), suggest the direction of organizational structuring, including: "A planned process in which applied behavioral science principles and practices are introduced into an ongoing organization towards the goals of implementing organizational competence and greater organizational performance".

This opinion explains that organizational structuring is a systematic planning process that applies the principles and practices of scientific individual behavior that are introduced in organizational activities continuously to achieve the goals of organizational improvement and better organizational competence and also better organizational performance.

Departing from the above thought, it appears that the success of an organization in carrying out its mission and vision is not enough to formulate or arrange a control system, but must also be accompanied by structuring the organization so that the organization is able to utilize its apparatus effectively and be able to work efficiently, so that it can encourage improving performance employee as a whole. On that basis, the organization's control and restructuring system is believed to be a variable capable of solving the problems of employee performance in the organization as a whole.

Performance of the organization referred to is the completion of quality work, on time accompanied by the quality and quantity of work produced in accordance with predetermined targets. Implementation of a job is considered to meet the right standard, when referring to work results in accordance with predetermined quality standards, so as to achieve the right results and targets, according to Jamari in Rivai (2009) states that employee performance "as an embodiment of the authority of duties and responsibilities which has been outlined by the organization". Thus the performance of employees is intended as a form of execution of tasks assigned to employees or officials in accordance with the authority of their superiors6. The realization of the employee's performance includes the employee's performance at the Office of Community and Village Empowerment as well as the National Unity and Politics in the City of Banjar.

The Office of Community and Village Empowerment as well as the National Unity and Politics of the City of Banjar, was formed based on the Regional Regulation of the City of Banjar Number 8 of 2016 concerning the Formation and Composition of the Regional Instruments of the City of Banjar. Based on the Banjar Mayor Regulation Number 30 Year 2016 concerning the Main Tasks, Functions and Work Procedures, the main 
tasks of the Office of Community and Village Empowerment as well as the National Unity and Politics of the City of Banjar are to carry out the preparation and implementation of regional policies in the field of Community and Village Empowerment and the Field of National and Political Unity.

The Office of Community and Village Empowerment and National and Political Unity are headed by a Head of Office. In carrying out its duties and functions, the Head of Service oversees 5 organizational units, including: Secretariat, Community and Village Empowerment Division, Nation and Political Unity Division, Office Technical Implementation Unit (UPTD) and Functional Position Groups. In addition, referring to Law Number 27 of 2002 concerning the Establishment of the Banjar City in West Java Province 2002 State Gazette of the Republic of Indonesia Number 130, Supplement to the State Gazette of the Republic of Indonesia Number 4246.

Referring to the Main Tasks and Functions above, it can be seen that the tasks carried out by the Office of Community and Village Empowerment as well as the National Unity and Politics of the City of Banjar with all the problems they face are experiencing difficulties in implementing their various programs. The process of achieving organizational goals in accordance with the main tasks and functions will be smoother, if the performance of employees runs appropriately in accordance with existing procedures. Employee performance that is not supportive or inappropriate will hamper the achievement of optimizing the targets to be achieved by the Office of Community and Village Empowerment and the National Unity and Politics of the City of Banjar.

Based on the field findings, the performance of employees at the institution has not run according to the existing rules, causing the work to run optimally. The results of researchers' observations related to the performance of the employees of the Office of Community and Village Empowerment as well as the National Unity and Politics of the City of Banjar, found several problems identified.

The quality of work of employees is not in line with expectations, as planned and determined by the Head of Service. For example: in the Field of Empowerment and Village Communities (PMD), among others are related to the preparation of plans and programs of the scope of institutions, community economic development and TTG, community self-sufficiency and participation as well as village (kelurahan) apparatus and development do not meet the expected quality standards and are not in accordance with standard work results as done in other cities in Indonesia as the results of comparative studies Head of Office to other cities, such as to the city of Surabaya. Although of the 10 existing programs arranged, it turns out that 5 programs can be implemented in one fiscal year plus the quality is not adequate as expected.

The Quantity of work produced by the employees has not shown results that have been determined as targets set by the department. For example: in the Field of National Unity and Politics (Kesbangpol), among others relating to coaching, coordinating, controlling, supervising program activities in the field of national and political unity, 12 
programs are formulated in one fiscal year, in fact only 6 programs can be run, while 6 other programs have not been able to run due to constraints related to the ability of the apparatus and the number of staff assigned is very limited, while the existence of the Village Community Empowerment Office and the National Unity and Politics of the City of Banjar the scope of its work area and duties is very broad.

Employee reliability cannot be expected yet because of the limited ability, skills and insight of employees. For example: in the Head of Planning and Finance, among others those related to the drafting of the concept of community and village empowerment program planning, national and political unity, do not yet have the expected work competence. The planning concept that was compiled was not in accordance with the Budget Work Plan (RKA) and Annual Work Plan (RKT) and Government Institution Performance Accountability Report (Lakip) and Strategic Plan (Renstra), so that between the plans arranged with RKA and RKT from Lakip and Renstra were less related to the direction and target. The constraints relate to the ability of human resources in understanding the task not in accordance with the expected capabilities.

Based on the problems outlined above, the purpose of this study is to analyze the effect of the Organizational Control and Structuring System on Employee Performance in the Community and Village Empowerment Agency, National Unity and Politics in Banjar City.

\section{B. Literature ReVIEW AND HyPOTHESIS}

In essence, an organization needs a management control system to guarantee the implementation of an organizational strategy effectively and efficiently, so that organizational goals can be achieved. Organizations need a management control system to guarantee the implementation of organizational strategies effectively and efficiently, so that organizational goals can be achieved. Control activities according to Mahmudi (2007) can be done through activity planning, coordinating activities, communicating information, evaluating information, making decisions and influencing people in organizations to change behavior.

The activities above, are an important part of management, there is even an anecdote that says that good management requires effective control. Even good planning, clearly stated goals, organizational structure and motivation will not be able to deliver organizational success without the support of an adequate management control system. In this regard, Lekantopessy (2011), revealed that the management control system had a positive effect on company capability.

The main analysis used in this framework of thinking relating to the control system, put forward by Anthony and Govindarajan (2005) suggests that the elements of the control system are the detector is a device that measures something that happens in the process being controlled, the assessor is a device that determines the significance of an actual event by comparing it with some standard or expectation of what should happen, 
the effector of a device (often referred to as 'feedback') that changes behavior, if the indicator indicates the need for feedback and communication network devices that forward information between the detector and the processor and between the processor and effector.

The four elements above, are the main elements in the control system, the implementation requires a variety of types that function as detectors, processors, effectors and communication networks, so that the implementation of control can run effectively. Practically a variety of elements are used by managers, ranging from conventional models to the easiest ways by utilizing information technology. At the private level or public organizations, electronic types have been used that use Closed Circuit Television (CCTV) and the Online Application System and other modern technologies to detect various activities.

The success of public organizations in achieving their goals is not enough just with an effective management control system, but it is also necessary to take another step, namely by organizing the organization, so that the direction and goals and objectives of the organization are achieved. According to Wahid's Hammer and Chammpy translation (1995), suggests 4 key factors in organizing the necessary organizational arrangements, including:

1. Fundamental, structuring the organization on fundamental issues, namely the vision, mission, goals of the organization and the rules that underlie the operation of the organization.

2. Radical, the organizational structuring process must go to the root of the problem and not the face, so that the organization looks good from the outside, even though it is not good inside.

3. Dramatic, Organizational structuring is not intended to produce marginal but rather those which are task-oriented new breakthroughs.

4. Process, Organizational structuring must be oriented to the work process of an organization, not oriented to tasks, jobs, people or structures.

The factors above, it appears that organizational structuring needs to be done, but it must be fundamental, rooted and breakthrough towards work processes that are planned, orderly and emerge towards re-engineering to make changes that are better and developing. According to the Udaya translation of Robbins (1996), the organizational arrangements were grouped into four categories, including:

1. Structural arrangement, including changes in authority relationships, coordination mechanisms, job redesign or similar structural variables.

2. Structuring technology, including modifications in the workings that are processed in the methods and equipment used.

3. Structuring physical settings, including changes in space and layout and workplace settings. 
4. Structuring people, refers to changes in attitudes, skills, expectations, perceptions and behavior of employees.

The four categories of organizational structuring above, carried out so that the organization can achieve its objectives effectively to achieve better work results than the previous work to achieve optimal employee performance. To achieve optimal performance Mahmudi (2007) suggests important factors that affect performance, including personal / individual factors, including: knowledge, skills, confidence, motivation and commitment possessed by each individual, leadership factors, includes: quality in providing encouragement, enthusiasm, direction and support provided by managers and team leaders, team factors, including the quality of support and enthusiasm provided by colleagues in a team, trust in fellow team members, teamwork and cohesiveness, team factors, includes: work systems, work facilities or infrastructure provided by the organization, organizational processes and performance culture within the organization, and contextual (situational) factors, including: pressures and changes in the external and internal environment.

Based on traditional performance appraisal systems, performance is only associated with personal factors, but in reality performance is often caused by other factors outside personal factors such as systems, situations, leadership or teamwork. According to Mangkunegara (2004) there are four employee performance factors that become the standard for evaluating work results, including quality of work, including accuracy, accuracy, skills and cleanliness, work quantity, including routine and non-routine or extra output, reliability or unreliable performance, including whether or not to follow instructions, abilities, initiatives, caution and crafts, and work attitudes, including: the attitudes of other employees, work and cooperation with the organization.

The factors above appear that the employee's performance is shown by the quality of the individual, the quantity of individual work, reliable in carrying out the work and has a responsible work attitude towards all tasks assigned to the employee.

Mahmudi (2007) states that: "Management control systems are related to various functions of public administration, ranging from planning activities, coordinating between work units, changing or structuring the organization and making decisions, all of which are aimed at achieving better performance".

Furthermore Mahmudi (2007) also revealed that "to create public sector organizations that have high performance, organizations need to have a performance management system that is integrated with management control systems".

The opinion of Hammer \& Chammpy (1995), which states that: "organizational structuring in the form of a rethinking fundamentally and radically designing work processes is intended to get improvements to employee performance".

Based on the identification of the problem and background above, the authors propose the following hypothesis: 
1. System controlling determined by the element of the tracker (detector), the element of assessor (assessor), the element of the effector (Effector) and the element of the Communication Network (Communication Factor) has a positive effect on employee performance in the Office of Community and Village Empowerment and the National Unity and Politics of the City of Banjar.

2. Organizational Structuring determined by the Structuring Structuring category, the Technological Arrangement category, the Physical Arrangement category and the Structuring of People category have a positive effect on the Performance of Employees in the Community and Village Empowerment Office as well as the National Unity and Politics of the Banjar City.

3. Organizational Control and Structuring System has a significant effect on the Performance of Employees in the Office of Community and Village Empowerment as well as the National Unity and Politics of the City of Banjar.

\section{MethoD}

The research method used in this study was an explanatory survey. The population in this study is the Office of Community Empowerment, Villages, National Unity and Politics of Banjar City with a target population of 601 people. The number of respondents taken based on Simple Random Sampling is 240 people.

Data collection techniques used in carrying out this research are the Study of Literature, Observation, Interview, and Questionnaire. Before the questionnaire is used in data collection, the validity and reliability of the research measuring instrument (questionnaire) will be tested first. Validity test is done by correlating the score for each item with the total score through the Person correlation formula, while the reliability test uses the Cronbach alpha coefficient formula. The data analysis technique used to test the model and the hypothesis used is the Structural Equation Model (SEM) analysis.

\section{RESUlt AND DISCUSSION}

The results of the validity and reliability test showed that each questionnaire had shown good validity and reliability. This is indicated by the value of $\mathrm{r}$ or the correlation value between the item suspension with the total shows a significant coefficient and has a reliable reliability value. The results of SEM data analysis which include evaluations of measurement models and structural models. Evaluation of the measurement model includes: (1) evaluation of the validity of the measurement model by looking at the $t$ factor loadings greater than the critical value ( $\geq 1.96$ or if rounded $\geq 2$ ) and the value of the standardized factor load (standardized factor loading) $\geq 0.30$; and (2) evaluation of the reliability of the measurement model using the CR (composit reliability measure) and VR (variance extracted measure) values with the requirements: CR $\geq 0.70$ and $\mathrm{VR} \geq$ 0.50 . The evaluation results are summarized briefly as follows: 
Table 1

Evaluation of Measurement Model Validity

\begin{tabular}{|c|c|c|c|}
\hline $\mathrm{X}_{1}$ & SLF $^{*}$ & t-Value ${ }^{* *}$ & Validitas \\
\hline $\mathrm{X}_{1-1}$ & 1,01 & 19,69 & Good \\
\hline $\mathrm{X}_{1-2}$ & 0,82 & 19,00 & Good \\
\hline $\mathrm{X}_{1-3}$ & 0,83 & 17,30 & Good \\
\hline $\mathrm{X}_{1-4}$ & 0,80 & 17,21 & Good \\
\hline$X_{2}$ & SLF $^{*}$ & t-Value ${ }^{* *}$ & Validity \\
\hline $\mathrm{X}_{2-1}$ & 0,91 & 17,00 & Good \\
\hline$X_{2-2}$ & 0,86 & 19,75 & Good \\
\hline$X_{2-3}$ & 0,91 & 20,19 & Good \\
\hline$X_{2-4}$ & 0,84 & 14,66 & Good \\
\hline $\mathbf{Y}$ & SLF* & t-Value ${ }^{* *}$ & Validity \\
\hline $\mathrm{Y}_{1}$ & 0,82 & 21,05 & Good \\
\hline $\mathrm{Y}_{2}$ & 0,94 & 21,27 & Good \\
\hline $\mathrm{Y}_{3}$ & 0,89 & 21,68 & Good \\
\hline $\mathrm{Y}_{4}$ & 1,00 & 21,84 & Good \\
\hline
\end{tabular}

Source: Analisys Research Data, 2019.

Model reliability in SEM data analysis techniques is based on the results of CR (composit reliability measure) and VR (variance extracted measure) calculations which are summarized in the following table:

Table 2

Evaluation of Measurement Model Reliability

\begin{tabular}{|l|c|c|c|}
\hline \multicolumn{1}{|c|}{ Variable } & CR & VE & Reliability \\
\hline Bureaucratic Reform & $0,96 \geq 0,70$ & $0,85 \geq 0,50$ & Good \\
\hline Apparature Competence & $0,96 \geq 0,70$ & $0,87 \geq 0,50$ & Good \\
\hline Organizational Performance & $0,97 \geq 0,70$ & $0,90 \geq 0,50$ & Good \\
\hline
\end{tabular}

Source: Analisys Research Data, 2019.

Furthermore, to see the results of the evaluation of the structural model in this study and its relation to the hypotheses of the research that were built previously, summarized in the following table:

Table 3

Evaluation of Structural Models and their Relation to Hypotheses

\begin{tabular}{|c|c|c|c|c|l|}
\hline Hypotheses & Relation & SLF & T - Value & $\mathbf{R}^{2}$ & \multicolumn{1}{|c|}{ Result } \\
\hline 1 & $\mathrm{X} 1 \rightarrow \mathrm{Y}$ & 1,07 & 2,69 & - & $\begin{array}{l}\text { Positive and Significant (Hy- } \\
\text { pothesis 1 is accepted) }\end{array}$ \\
\hline 2 & $\mathrm{X} 2 \rightarrow \mathrm{Y}$ & 2,10 & 5,12 & - & $\begin{array}{l}\text { Positive and Significant (Hy- } \\
\text { pothesis 2 is accepted) }\end{array}$ \\
\hline 3 & $\mathrm{X} 1$ dan $\mathrm{X} 2 \rightarrow \mathrm{Y}$ & - & - & 0,87 & $\begin{array}{l}\text { Positive and Significant (Hy- } \\
\text { pothesis 3 is accepted) }\end{array}$ \\
\hline
\end{tabular}

Source: Analisys Research Data, 2019

Simultaneous discussion of the influence of Organizational Control and Organizational System variables on Employee Performance at the Community and Village Empowerment Office and the National Unity and Politics of Banjar City and the partial influence of elements of the Control System and Organizational Structuring categories 
on Employee Performance at the Community and Village Empowerment Office and the National Unity and Politics of the City of Banjar are described as follows.

The results of the analysis of the Sub Structure of the Standardized Solution Variable X1 Model determined by X1-1 through X1-4 influence on Y, showing the standard loading factor of the Control System on Employee Performance of 1.07. Based on these values, the Control System Variable which consists of elements: Trackers, Assessors, Effectors and Communication Networks are stated to have a positive effect on Employee Performance at the Office of Community and Village Empowerment and Unity Banjar City Nation and Politics. While seen from the T-value analysis, the value of the Control System on Employee Performance is 2.69. This value indicates that the Control System variable consisting of elements: Detector, Assessor, Effector and communication network significantly influence Employee Performance at the Office of Community and Community Empowerment and National Unity and Politics of the City of Banjar.

The Tracking Element in measuring the Control System in the Office of Community and Village Empowerment as well as the National Unity and Politics of the City of Banjar based on the structure of the main standardized solution model is able to explain 1.01. While seen from the structure of the main $t$-value model, the value of the trace element value is 19.69, meaning that the Tracking Element is the right element to measure the Control System at the Office of Community and Village Empowerment and the National Unity and Politics of Banjar City. Tracking elements consisting of indicators: Monitoring employee activities, detecting employee actions and measuring data accuracy, have been carried out by the Head of the Community and Village Empowerment Office and the National Unity and Politics of the City of Banjar, so as to be able to improve overall Employee Performance at the Office of Community and Village Empowerment and National Unity and Politics of the City of Banjar.

The Assessor Element in measuring the Control System in the Office of Community and Village Empowerment as well as the National Unity and Politics of the City of Banjar through the structure approach of the main standardized solution model, is able to explain the control system of 0.82 . While seen from the structure of the main $t$-value model, the value of the value of the appraisal element is 19.00, meaning that the Appraiser Element is an element that is proven to be appropriate for measuring the Control System in the Office of Community and Village Empowerment and the National Unity and Politics of the City of Banjar. Appraisal Elements consisting of indicators: Evaluation of employee actions, Comparing various events and Calculation of information deviation, have been fully carried out by the Office of Community and Village Empowerment and National Unity and Politics of the City of Banjar, so as to have been able to improve overall the Performance of Employees at the Office of Community and Village and Community Empowerment Services Banjar City Nation and Politics. 
The Affector Element in measuring the Control System at the Office of Community and Village Empowerment as well as the National Unity and Politics of the City of Banjar based on the main model structure of the standardized solution has been able to explain at 0.83 . While seen from the main structure of the $t$-value model, the value of the affector element value is 17.30, meaning that the Afector Element is a very appropriate element to measure the Control System at the Office of Community and Village Empowerment and the National Unity and Politics of the City of Banjar. The Afektor element which consists of indicators: Changing work irregularities, Changing work errors and Revising changes in procedures, has been carried out by the Head of the Office of Community and Village Empowerment and the National Unity and Politics of the City of Banjar, so as to improve overall Employee Performance at the Office of Community and Village Empowerment and National Unity and Politics of the City of Banjar.

Elements of a communication network in measuring the Control System in the Office of Community and Village Empowerment as well as the National Unity and Politics of the City of Banjar based on the structure of the main standardized solution model has been able to explain 0.80. While seen from the main structure of the $t$-value model, the magnitude of the value of communication network elements is 17.21, meaning that the Communication Network Element is a very appropriate element to measure the Control System at the Office of Community and Village Empowerment and the National Unity and Politics of the City of Banjar. Elements of a communication network consisting of indicators: Communication of subordinate superiors, two-way communication and communication based on procedures, has been carried out by the Office of Community and Village Empowerment and the National Unity and Politics of the City of Banjar, so as to improve Overall Employee Performance at the Office of Community and Village Empowerment and National Unity and Politics of the City of Banjar.

The results of the analysis of the Sub Structure of the Standardized Solution Variable X1 Model determined by X2-1 through X2-4 influence on Y, showing that the standard loading factor of Organizational Organizational Structuring on Employee Performance is 2.10. Based on these values, the Organizational Structuring Variables consisting of Structural Structuring Categories, Technology Structuring Categories, Physical Setting Structuring Categories and People Structuring Categories are stated to have a positive effect on Employee Performance at the Office of Community and Village Empowerment and the National Unity and Politics of Banjar City. While seen from the tvalue analysis, the value of Employee Organization Structuring on Employee Performance is 5.12. These values indicate that the variable Organizational Structuring Employees consisting of Structural Structuring Category, Technological Structuring Category, Physical Setting Structuring Category and Managing Structuring Category are stated to have a significant effect on Employee Performance in the Office of Community and Village Empowerment and National Unity and Politics of Banjar City. 
The category of Structuring in measuring the Structuring of Employee Organizations in the Office of Community and Village Empowerment as well as the National Unity and Politics of the City of Banjar was able to explain the Organizational Structuring variables based on the analysis of the main model structure of the standardized solution of 0.91 . While seen from the main $t$-value model structure, the magnitude of the value of the structural structuring category is 17.00. The figures above have stated that the Organizational Structuring Category is an appropriate component to measure the Organizational Structuring of Employees in the Office of Community and Village Empowerment as well as the National Unity and Politics of the City of Banjar. Structure structuring category consisting of indicators: Employee work list, Dividing workload and Establishing coordination mechanisms, have been implemented by the Office of Community and Village Empowerment and National Unity and Politics of the City of Banjar, so it able to improve overall Employee Performance at the Office of Community and Village Empowerment and National Unity and Politics of the City of Banjar.

The category of Technology Arrangement in measuring the Organizational Structuring of Employees at the Office of Community and Village Empowerment as well as the National Unity and Politics of the City of Banjar has been able to explain Organizational Structure based on the analysis of the main model structure of the standardized solution of 0.86 . While seen from the $t$-value main model structure, the magnitude of the value of the Technology Arrangement category is 19.75. These figures indicate that the Technology Arrangement Category is the right component to measure the Organizational Structuring of Employees at the Office of Community and Village Empowerment as well as the National Unity and Politics of the City of Banjar. This Technology Arrangement category consists of indicators: Modification of work results, Arranging work methods and equipment Recycling, has been carried out by the Office of Community and Village Empowerment and National Unity and Politics of the City of Banjar, so its able to improve overall Employee Performance at the Office of Community and Village Empowerment and National Unity and Politics of the City of Banjar.

The category of structuring physical settings in measuring the Organizational Structuring of Employees at the Office of Community and Village Empowerment as well as the National Unity and Politics of the City of Banjar was able to explain the categories of physical setting structuring based on the analysis of the main model structure of standardized solutions capable of explaining organizational structuring of 0.91 . While viewed from the main $t$-value model structure, the magnitude of the value of the category of physical arrangement structuring is able to explain the organizational arrangement of 20.19, meaning that the category of physical setting is an appropriate component to measure the Organizational Structuring of Employees at the Office of Community and Village Empowerment and National and Political Unity Banjar City. The category of structuring physical settings consisting of indicators: Ordering workspace, Arrangement of layout and adequate work equipment, has been carried out by 
the Head of the Office of Community and Village Empowerment as well as the National Unity and Politics of the City of Banjar, so its be able to improve overall the Performance of Employees at the Office of Community and Village Empowerment and National Unity and Politics of Banjar City.

The category of Structuring People in measuring the Structuring of Employee Organizations in the Office of Community and Village Empowerment as well as the National Unity and Politics of the City of Banjar has been able to explain Organizational Structuring based on the analysis of the main model standardized solution structure of 0.84 . While seen from the analysis of the main model of the $t$-value structure, the magnitude of the value of the People Structuring category is 14.66. These figures indicate that the People Structuring Category is an appropriate component to measure the Organizational Structuring of Employees at the Office of Community and Village Empowerment as well as the National Unity and Politics of the City of Banjar. The category of structuring people consists of indicators: Development of work awareness, encouraging creative work and training of work skills, has been carried out by the Office of Community and Village Empowerment as well as the National Unity and Politics of the City of Banjar, so its be able to improve overall Employee Performance at the Office of Community and Village Empowerment and National Unity and Politics of the City of Banjar.

Before discussing the simultaneous influence of the Organizational Control and Structuring System on Employee Performance at the Office of Community and Village Empowerment as well as the National Unity and Politics of the City of Banjar. The results of the analysis through SEM calculation can be stated that the Control System variable (X1) has a positive effect on Employee Performance (Y) in the Office of Community and Village Empowerment as well as the National Unity and Politics of the City of Banjar of 1.07. While the Organizational Structuring variable (X2) positively influences Employee Performance (Y) in the Office of Community and Village Empowerment as well as the National Unity and Politics of Banjar City by 2.10. Thus based on the results of the simultaneous SEM calculation of the Organizational Control and Structuring System Variables (X1 and X2) the dominant influence on Employee Performance (Y) in the Office of Community and Village Empowerment as well as the National Unity and Politics of Banjar City.

The magnitude of influence is dominantly shown in SEM calculation results that simultaneously Control System variable (X1) and Organizational Structuring variable (X2) have been able to explain the Employee Performance variable $(Y)$ at the Office of Community and Village Empowerment and National Unity and Politics of Banjar City by $87 \%$. The magnitude of these values indicate that simultaneously the variable Control and Organizational Structuring System significantly influences the Performance of Employees in the Office of Community and Village Empowerment as well as the National Unity and Politics of the City of Banjar. 
Listening to the results of the above research, it appears that the magnitude of the influence of the Organizational Control and Structuring System on Employee Performance in the Office of Community and Village Empowerment and the National Unity and Politics of the City of Banjar, shows that the two independent variables are important variables to solve the problem of employee performance as said by Moeheriono (2009) that management control systems are related to various functions of public administration, ranging from activity planning, coordination between work units, organizational change or structuring and decision making, all of which are aimed at achieving better performance. Whereas organizational structuring is said to be Hammer and Chammpy (1996) that organizational structuring in the form of fundamental rethinking and radical design of work processes is intended to obtain improvements to employee performance. This opinion has been proven in this study that the variable Control and Organizational Structuring System is very influential on the performance of employees at the Office of Community and Village Empowerment and the National Unity and Politics of the City of Banjar.

\section{E. CONCLUSION}

Partially the Control System variable has a positive influence on employee performance at the Office of Community and Village Empowerment and the National Unity and Politics of the City of Banjar. Partially, the Organizational Structuring variable has a positive influence on employee performance in the Office of Community and Village Empowerment as well as the National Unity and Politics of the City of Banjar, even though seen from its categories, the values are quite varied. The results of the study showed that the categories of structuring and arrangement of settings gave the strongest influence, while the other categories were: the category of technology structuring and the category of structuring people although showing a smaller effect, but still showing a positive effect.

Simultaneously the variable Control and Organizational Structuring System positively influences the Performance of Employees in the Office of Community and Village Empowerment as well as the National Unity and Politics of the City of Banjar. This implies that the Organizational Control and Structuring System can improve Employee Performance in the Office of Community and Village Empowerment as well as the National Unity and Politics of the City of Banjar.

\section{REFERENCES}

1. Anthony, R. N. \& Govindarajan, V. (1995). Management Control Systems. New York: McGrawHill.

2. Anthony, R. N., \& Govindarajan, V. (2005). Management Control System. Jakarta: Salemba Empat. 
3. Banjar City Regional Regulation No. 8 of 2016 concerning the Formation and Composition of the Banjar City Regional Apparatus.

4. French, W. L., \& Bell, C. H. (1981). Dimensions of Organizational Behavior. New York: McMillan Publishing Co. Inc.

5. Hammer, M., \& Cahammpy, J. (1995). Rekayasa Ulang Perusahaan. Jakarta: Gramedia.

6. Law Number 27 of 2002 concerning the Establishment of the Banjar City in West Java Province.

7. Lekatompessy, J. E. (2011). Peran Sistem Pengendalian Manajemen Dalam Meningkatkan Kinerja Perusahaan: Analisis Kontinjensi Dan Resource-Based View (Doctoral dissertation, Program Pascasarjana Undip).

8. Mahmudi. (2007). Manajemen Kinerja Sektor Publik. Yogyakarta: Sekolah Tinggi Ilmu Manajemen YKPN.

9. Mangkunegara, A. A. A. P. (2004). Manajemen Sumber Daya Perusahaan. Bandung: Remaja Rosda Karya.

10. Moeheriono. (2009). Pengukuran Kinerja Berbasis Kompetensi. Bogor: Ghalia Indonesia.

11. Mulyadi \& Setiawan, J. (2001). Sistem Perencanaan dan Pengendalian Manajemen. Jakarta: Salemba Empat.

12. Rivai, V. (2009). Manajemen Sumber Daya Manusia. Jakarta: Raja Grafindo Persada.

13. Robbin, S. P. (1994). Teori Organisasi. Jakarta: Arcan.

14. Salim, K., \& Sari, M. P. (2014). Pengaruh Globalisasi Terhadap Dunia Pendidikan. Makalah Jurusan Manajemen Pendidikan Islam, STAI Abdurahman Kepulauan Riau. Page, 1-11.

15. Thereana, A. (2018, July). Merajut Kearifan Lokal Melalui Proverb pada Era Global. In Prosiding Seminar Nasional Program Pascasarjana Universitas PGRI Palembang (Vol. 5, No. 05). 